\title{
Effect of Aerobic Bacterial Infection to The Semen Parameters ${ }^{\star}$
}

\author{
*Asma'a J.Al-Taee **Abbas Al- Dajaily \\ *The State Company for Drug Industries and Medical \\ Appliances \\ **Tikrit University/ College of Medicine
}

\begin{abstract}
الملخص
اجريت فحوصات السائل المنوي وزرع السائل المنوي في هذه الدراسه علـى 105

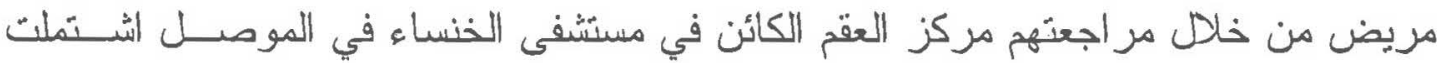
الفحوصات فحص السائل المنوي وفحص زر ع السائل المنوي و التي تضمنت ما يلي في فري

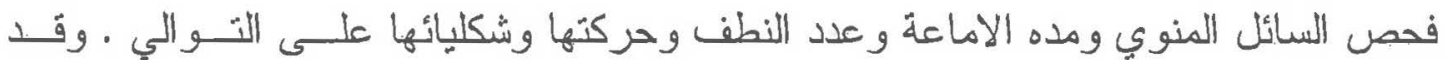

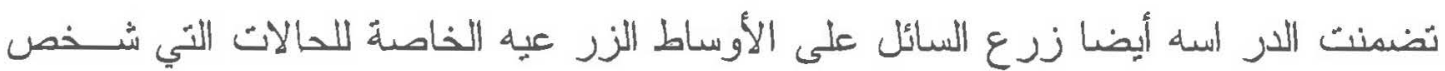

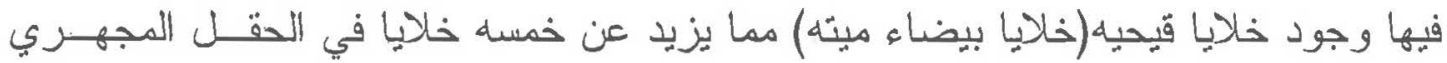
الواحد ز تم اجر اء زر ع السائل المنوي واجر اء فحص الحساسيه وقد تبين من هذه الدراسه ان انداء 21 مريض لديهم خلايا قيحيه وان اكثر مسببات البكتيريه شيوعا هـي بكتريــا العنقوديسه الموجبه لصبغة بنسبه 16\% ، ومن ثم وبالدرجه الثانية البكثريا المعويه بنسبة 4\% و واخيـرا

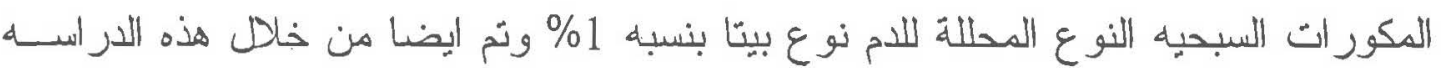
فياس عدد الجيامن للملمتر الواحد بالإضـافة لقياس حيويه الحيامن الحيه و الخاملـهـ و الميتــهـ

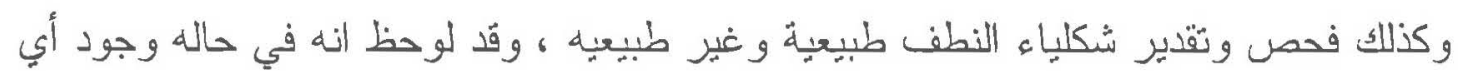
خلل في إحدى المقاييس الطبيعية للسائل المنوي يكون مصاحبا بوجود أصابه بكثريا.
\end{abstract}

\section{Abstract}

Semen analysis and culture assay were done (100) patients suspected to be subfertile men attended the male infertility clinic at Al-Khansa'a hospital in Mosul. The following parameters of semen are studied such as: semen volume liquefaction time sperm count, sperm motility and sperm morphology.

Culture have been made in patients with abnormal semen and have pus cells more than 5 cells in High Field Power (HFP). The most common abnormalities in the semen are decreased sperm count and /or decreased sperm motility. Culture and differential stain of patients' semen of

'Presented at the first conference on Biology, University of Mosul, college of Education, 4-5 September 2007 
infertile men shows a significant negative correlation to sperm count and sperm motility (When sperm count decreases sperm motility increases),Azoospermia and Oligospermic men show a significant increase infection hapends as a compared to their non infected

\section{Introduction}

Infertility is defined as the inability to conceive and it is due to various socio-biological factors consultations for inability have been increased in the last few years . the man alone is cause of inability in about one fifty of cases (1).

Since inability in man can result form a wide range of various causes, man should be evaluated history, complete physical examination, examination of the ejaculate . for the purpose of physical diagnosis , semen analysis can give much information about the state of inability. Sperm count is helpful in azoospermia and severs olgospermia when the physician knows the letter is a barometer of testicular damage

A couple is considered to be infertile after unsuccessfully attempting pregnancy for I year. Infertility is termed primary when it occurs without any prior pregnancy and secondary when it follows a previous conception. Some conditions such as azoosperima. Endometriosis and tubalocclusion are more common in woman with primary inability but virtually all conditions occur in both settings makind the distinction of litter benefit (2) . male fertility depends on the production of adequate numbers of healthy spermatozoa by the semeniferous tubules their subsequent delivery into the upper vagina from where a smell proportion of them will penetrate the cervical mucus travel through the uterus and them to the ampullary portion of the fallopian tubes where fertilization normally takes place.

Semen it is a fluid composed of spermatozoa and seminal plasma. The former originating in the testicles contribute to about $50 \%$ or less of the seminal fluid volume, as it had been shown by measurement of the packet sperm volume (PSV).The seminal plasma is mainly made of secrations from the eqididymis, seminal vesicles, prostate and bulbourethal glands .

The composition of human semen carnitine which is concentrated by the eqididymis from blood serves as enrgy source for sperm to develop motitlity. Secretions from the seminal vesicles (about 60\%) contain fructose and prostaglandins which are important for sperm motility .

These secretions also contain fibrinogen-like substance responsible for coagulation of semen .The prostatic secretion (about20\%) contain fibrino lysine enzyme responsible for liquefaction of semen within 10-30 minutes . These secretions also contain acid phosphatase, calcium, zinc, 
citric acid and spermine with it's bacterio static action . Many attempts have been made to define normal sperm count in the post, sperm count less than $60 \mathrm{million} / \mathrm{ml}$ were considered as oligospermia, subsequently the number was lowered to less than $40 \mathrm{million} / \mathrm{ml}$ and nowadays counts of $20 \mathrm{million} / \mathrm{ml}$ are considered to be the lower limit of normal count .

\section{Revew of literature}

Causes of inability can be classified into pretesicluar, testicular and post testicular (3)

1. pretesticular causes

1.2. hypogonadortopian

It is characterized cryptorchidiism , gonadotropin deficiency and with or with out olfactory the defect is at the hypothalamic level with absence or inadequate release of $\mathrm{LHRH}$ and thereis lack of responsiveness to exohenous hondotropin administration

\subsection{Estrogen excess}

In patients with liver cirrhosis have increased estrogen level in blood which results in inhibition of gonadotropin secretion by the anterior pituitary . gland and secondary testicular failure .

\subsection{Androgen excess}

Excesss testosterone cause inhibition of spermatogenesis by its negative feed back inhibition of FSH secretion by the anterior pituitary high testosterone causes a reversible reduced fertilizing capacity of the sperms in serves as areversible male contraceptive agent .

\section{5. hyperprolactinemia}

This can be due to pituitary adenoma, hypothalalamic dysfunction, drug induced or idiopathic. Hyperprolactinemia may cause secondary testicular dysfunction. High prolactin may result in low semen -volume, low or normal spern motitity, impotence, galactorrhea and infertility . in cases of hypothalalamic the seminiferous tubules may be associated with low serum testosterone concertration found the meanprl level in the serum of infertile men was higher than that infertile men . Impaired spermatogenesis is found in hypothalalamic men however found that there was no difference in mean prl levels in the serum of men with normal sperm count and with oligospermia or a zoo spermia .

\subsection{Gluco corticoid excess}

hyper cortisdism in cushing 's syndrome decrease LH secretion decreases testosterone secretion and loads to secondary testicular failure. Patent who are under steroid therapy for other diseases may develop oligo spermia and infertility .

1.7. hypothyroidism 
Patients with hypothalalamia may have decreased spermatogenesis hypothyroid patients often restore fertility after thyoxine supplement .

1.8. Hyperthyroudism

it has been noted that thryotoxicosis is associated with low sperm count and maturation arrest. It is associated with decreased sperm count, serum volume and increased serum testosterone. These changes are secondary to elevated estrogen levels .

\subsection{Diabetes mellitus}

Uncontrolled diabetes mellitus may result in impotence and

Retrograde ejaculation. Semen is contaminated by urine, this result in great decrease of sperm motility and in fertility .

\subsection{Stress}

stress of any kind may result in infertility due to poor semen quality such as abnormal forms or an increase in immature forms (3).

1.10 General illness

Uremia patients develop infertility either by their action on adrenergic nervous system causing disturbance of ejaculation and erection or by causing hyperprolactinemia ureamic patients have decreased testosterone production with elevated gonadtropins indicating a defect at testicular level. These patients are also zinc deficient .

2. Testicular

2.1. Maturation arresti

because of ischemia which may result form trauma or torsion of the testis, there is damage of the spermatogenci epithium including the sertoli cells, while leydig cells are resistant and remain functionally normal . patients present with infertility have reduced size of the testis azoospermia with ahigh serum FSH level

\subsection{Hyposperatogenesis}

proportional hypoplasia of all germ cells .

2.3 germinal aplsia : (sertoli cells only syndrome)

here only sertoli : cells are present in the tubule, this may be associated with small but compensated leydig cell failure, the raised serum FSH level. But serum testosterone and LG are usually normal .

2.4 Klinefilters syndrome

This is a genetic disorder characterized by the destruction of the germinal epithelium as well leydig cells . the patient usually presents with sized testis, raised serum FSH level but normal LH level (4).

2.5 XYY syndrome

2.6 Other sex chromosomal or autosomalanomalics with gonadal involvement

\subsection{Cryptorchidism}


By the effect of abdominal temperature on the undescended testis, there is atrophy of germ cells and small immature tubules. if the changes are bilateral, the patient will have azoospermia, raised serum FSH but normal LH level (5).

\subsection{Radiation damage}

Exposure to radiation as in cases of tumor of in the germ region or in cases of lymphoma results in the destruction of germ cells especially the spermatogonia while leydig cells are resistant. The degree of damnge is dose dependent . below 600 rads the changes can be reversible and above this level the change can be permanent resulting in azoospermis and infertility . fractionated radiation may have more destructive effect than does a single radiation. men treated with radioactive iodine may also have impairment of spermatogenesis and elevation of serum FSH level.

2.9 Chemotherapy toxic agents

Many types of drugs cause damage to the seminferous epithelium . the most harmful ones are anti-cancar agents especially alkylating agents this may be associated with decreased serum testosterone level and increased serum testosterone level and increased serum LH due to impairment of leydig cells function .monoamine oxidase inhiditors cause reduction in sperm count even to the degree of azoospermia . furadantin causes temporary reduction in spermatogenesis resuling in a decreases sperm count and affect sperm motility. Cimetidin causes temporary reduction in spermatogenesis elevated serum testosterone level with no effect FSH level. Sulphasalzine is relaed toinfertility because removal of the drug results in improvement of quality and may also affect sperm motility .

2.10 mumps orchitis

Bilateral pubertal and postubestal mumps orchitis results in permanent damage to the seminiferous tubules leydig cells are usually preserved .The patents present with severe oliogosperima or azzoospermia unilateral involvement of the tests results in reduced sperm count but is compatidle with fertility .

2.11 Alcohol

Alcohol induces testicular atrophy by inhibition of gonadotropin secretion and destruction of the seminiferium. In addiyion it causes lydig cell failure which is manifested by loss of lidido, importance and infertility.

\subsection{Smoking}

Decreased sperm motility and count, low testosterone, high FSH levels were found in smokers. Nicotine depresses androgenic steroid. Prodction at testicular level by affecting lydig cells function. Serum estradiol levels were significantly higher in heavy smokers as compared to non- 
smokers. High percentage of morphologically abnormal forms of spermatozoa are seen in the ejaculate of smokers.

\subsection{Age}

The percentage of seminiferous epithelium in the parenchyma of the testis and the volume of somniferous epithelium per man is lower in old men (6).

\section{Postesticular causes}

3.1 block of the douct leading away from the test

Either congenital aphasia of the vas deferens or acquired obstruction

after infection as gonorrheal epididymitis lead to azoospermia and infertility .These causes have normalFSH level and testicular biopsy

3.2 Impaired sperm motility necessary for accurate diagnosis.

Various factors play a role in impairement of sperm motility and these include .

\section{3 prolonged abstinence}

long periods of abstinence affect semen quality including sperm motility.

\subsection{Pyospermia}

Pus form any source have deleterious effect on spern motility especially in patents with proven E.coli infection can reduce fertility are poorly understood.

\section{5 partial obstruction}

Characterized by severe oligospermia and severe asthenospermia with normal serum FSH level .

\subsection{Poly zoospermia}

Due to alarge number of spermatozoa in the ejaculate fructose is insufficient to maintain their motility.

\section{7 sperm agglutination and antibody}

The climping spermatozoa and the presence of sperm antibodies impair motility of sperms and their penetration of cervical mucus.

\subsection{Biochemical abnormalities of the seminal plasma}

Fructose is the main sugar in the seminal plasma and substrate for the metabolism of spermatozoa. The determination of fructose in seminal plasma provides a quantitative measure of seminal contribution to the make-up of human semen. It also serves as a diagnostic detection of ooclusion of the ejaculatory ducts. Fructose free azoospermic ejaculates were encountered in man with aplasia of vasa deferentia. Also determination of seminal and citric acid serve as indicators of the androgenic status of the male because secretory activity of the seminal vesicles depends upon the stimulatory effect of testosterone low levels of fructose in semen is sometimes associated with hypogonadism. Men whose prostatic fluid contains increased number of leucocytes, were 


\section{Asma'a J.Al-Taee \&Abbas Al- Dajaily}

found to have low concentration of zinc, magnesium, acid phosphate. However, found no difference in the mean co9ncentration of zinc, magnesium copper, alkaline,phosphate in seminal plasma of infertile men as compared to fertile men.

\subsection{Varicocele}

Varicocele occers when there is dilation of the pampiniform plexus resulting from incompetence of the values of the internal spermatic vein. Varicocele is one of the most common causes of infertility in the male .

In most causes Varicocele does not deteriorate the spermiogenic function only but also lower the sperm level of testicular androgens .

Patients with Varicocele have low sperm count,abnormal sperm morphologic features, increased baseline serum govadotopins as compared with fertile men without Varicocele .

However ,some workers demonstrated that there was no significant difference in serum $\mathrm{FSH}, \mathrm{LH}$ and testosterone between infertile men with Varicocele and normal fertile men.

classification of causes of male infertility pretesticular causes .

1. Hypogonadotropism

2. prepubertal onset

2.1. organic lesions in or near pituitary(tumers,cysts,trauma,etc)

2.2. gentic defects ingonadotropin secretion (hypogonadotrotropic eunucholdism )

2.3 Postpubertal onset :

organic lesions9pibuitary tumors on trauma to piluitary fossa)

Estrogen excess

1.Endogenous

a.Estrogen producing tumor (of the adrenal cortex for example

b. Cirrhosis of the liver)

2.Exogenous

Hyperrotaclinemia

Glucocorticoid excess

1.Endogenous

Cushing 's syndrome

2. Exogenous

a.treatment for ulcerative colites

b.treatment for chronic asthma

Hypothyrodism

Hyperthyrodism

Diabetes mellitus 


\section{Testicular causes}

\section{Maturation arrest}

Hypospermatodasis(proportional hypopasia of all germ cells).

Absence of germ cells(sentoli -cell-only-syndrome)

Klinefilter 's syndrome (XXY karyotype and it's variant's)

XYY syndrome

Other sexchromosomal or autosomal anomalies with gonadal involvement.

Crytoorchism

Radation damage

Chemo therapy

Mumpserchitis

\section{Posttesticular causes}

Block of ducts leading away from the test

4.1 Congenital

a. Aplasia of vasa deferentia

b. plasia of epididymis

4.2. Acquired:

a. Infection:
(1) Gonorrheal epididmitis
(2) Tuberculous epididmitis
(3) others

b. Vas ligation

(1) Voluntary

(2) Iatrogenic

Impared sperm motility (sperm count adequate ; testicularbiopsies normal)

1.Faulty maturation or improper storage of spermatozoa in the epididymis

2.Biochemical abnormalities of the seminal plasma

3.Genetic defects of the sperm tail (the immotile cilia syndrome )

1. Microscopic Examination

1.1 Sperm count

a. A diluting fluid is prepared by mixing $16 \mathrm{gm}$ of sodium bicarbonate and $4 \mathrm{gm}$ of phenol in $400 \mathrm{ml}$ distilled water.

b. White blood cell pipette.

c. Improved Neubaher hemocytometer chamber.

d. Clicker - counter.

The semen is mixed thoroughly and drawn up to the mark 0.5 of the white blood cell pipette. The diluting fluid is drawn up to the mark at the top of the bubble chamber. By this method 1:20 dilution is obtained the 
pipette is shaken well for 2 minutes few drops of the fliud are discarded from the pipette. Neubauer chamber is cover slipped, then both sides of it are filled with pipette mixture.

When a drop of semen is examined directly on cover slipped slide and the number of sperms are few, then 1:10 dilution is made by drawing up semen to the mark 1 then the pipette is filled with diluting fluid using clicker counter and X400 magnification the sperms are counted within 5 blocks, each block contain 16 small squares sperms overlying the upper and left lines of the square are eliminated and those overlying the right and lower lines of the square are counted. The total number within the 5 blocks 180 squares is obtained the sperm count $/ \mathrm{ml}$ is calculated as followes:

a. For the 1:20 dilution, six zeros are added to the total number in the 5 blocks.

b. For the 1:10 dilution by 2 , then six zeros are added to the figure obtained.

c. For the 1:10 dilution when the number of sperms is very few, all sperms present in the 25 block, are counted and five zeros are added to the figure.

\subsection{Sperm motility}

It is evaluted within $1 / 2$ to 1 hour after collection. The specimen is mixed well, then a drop of semon is placed on an ordinary micrope slide cover slipped and then examined using a magnification of X400 the percentage of spermatozoa moving with normal progressive motility is noted. In addition, the percentage of immotile sperms is recorded.

\subsection{Agglutinatioin}

A drop of semen is placed on amicroscope slide covered by a cover slip and observed for sperm agglutinatioin can be observed if present.

\subsection{Sprem morphology}

Eosin stain is prepared by addition of $100 \mathrm{ml}$ distilled water to $5 \mathrm{gm}$ of eosin ymayer's hematoxylin stain is prepared by dissolving $50 \mathrm{gm}$ of potassium alum in $1000 \mathrm{ml}$ distilled water, without heat, $1 \mathrm{gm}$ of hexatoxylin crystals are dissolved in this solution then $0.2 \mathrm{gm}$ of sodium iodine, $1 \mathrm{gm}$ citric acid and $50 \mathrm{gm}$ of chloralaydrate are added, the solution is shaken well. The fina color of the stain is reddish-violet.

Tincture of iodine is prepared by dissolving $50 \mathrm{gm}$ iodine and $100 \mathrm{gm}$ potassium iodine in $100 \mathrm{ml}$ distilled water and the solution is completed $1000 \mathrm{ml}$ by distilled water.

\section{Preparation smear}

A drop of semen is placed near the end of an ordinary microscope slide and with another slide the semen os spread from one side of the slide to the other side. 


\section{Fixation}

a. The following steps are used for fixation of the smear while wet, the smear is immersed in a solution composed of 2 parts $7 \%$ corrosive mercuric chloride and 7 part absolute, alcohol for $1 \mathrm{~min}$.

b. Then the slide is immersed in $50 \%$ alcohol for $1 / 2 \mathrm{~min}$.

c. Then immersed in $100 \mathrm{ml}$ distilled water and 2 drops tincture of iodine for $1 / 2 \min$

d. Finally it is washed in distilled water.

2. Staining

a. The slide is immersed in $5 \%$ aqueous eosin for $1 / 2 \mathrm{~min}$.

b. Then it is immersed in $100 \mathrm{ml} 50 \%$ alcohol and 2 drops concentrated $\mathrm{HCl}$ for $1 \mathrm{~min}$.

c. It is washed in distilled water.

$\mathrm{d}$. The slide is then immersed in hematoxylin for $2-5 \mathrm{~min}$.

e. After wards it is washed in distilled water, dried and examined.

The slide is examined using oil immersion lens, and the percentage of morphologically normal sperms is recorded in addition, the percentage of abnormal forms like tapered head, rounded head double head, immature cells, coiled tail are recorded.

Semen culture

All media culture prepared depend to the information from company produced to the media which is used and then sterilized in the autoclave in $121^{\circ} \mathrm{C}$ temperature under 15 pound/in ${ }^{2}$ pressure about $1 \mathrm{~min}$. these media are:

Blood Agar

MacConkey Agar

Chocolate Agar

Nutrient Agar

Diagnosis gram positive bacteria

The isolated bacteria diagnosed depended up on material provided from media and chemical material these are following:

1. Gram Stain

Tested the samples which are response to gram stain by its solution described from.

Complete B-haemolysis on solid blood media: Isolated colonies surrounded by complete zone of blood haemolysis (about regein haemolysis in diameter 2-4 ml) diagnosed its characteristics.

2. Diagnosis gram negative bacteria

Diagnosis depended upon

a. gram stain

b. tested the colony cultured above the MacConkey media from lactose formentation. 


\section{Results and Discussion}

Hundred patients(male) were participated in this study. The age of the subjects rang from 20 to 35 years.All of them were married and suffered from infertility. (Table1) shows the sperm count for all patients, 10 patients have a zoospermia, while 48 patients have a sperm count less than 20 million $/ \mathrm{ml}, 20$ patients have $20-40$ million $/ \mathrm{ml}$, 10patients have $80=100 \mathrm{million} / \mathrm{ml}$ out of total 100 cases. (Table2) shows the morphology of semen 's the abnormal ratio was $80.1-90 \%$ (210 which the less was at $40.1-50 \%$ which is considered normal morphology. The result of microorganism that isolated from culture of semen is shown in table ,staphylococcus aureus was found the most common bacteria that present in $16 \%$ of patient's semen. Isolated microorganism $1 \%$ then staphylococcus. B-hemolytic Streptococcus 4\%, while E. coli was the less predominant. (Table 4) shows the microscopical finding in semen: pus cells were found in 20 cases under 5 cell in fitting while R.B.C in 13 cases, epithelial tissue (debris) 17, candida sp. In 2, spermatocytes 5, urate arystale 8 , from total cases .

(Table 5) and (Table 6) shows the susceptibility pattern of E. coli and Staph aureus to different anti biotics respectively.

The cases without receiving antibiotic were highly susceptible to antimicrobial agents. shows the results of semen activity in this study, $60 \%$ was non motile, $25 \%$ active and $15 \%$ sluggish . The susceptibility test of isolated micro-organism appeared in the (Table 5) for 4 patients with E. coli infection appeared susceptibility to Tetracycline more than other antibiotics, the susceptibility of Staph aureus micro-organism appear to the ampicillin more than other antibiotics, and B. hemolytic streptococci appear susceptibility to rifampicin only.

Table(1) :Abnormal Sperm Count

\begin{tabular}{|c|c|}
\hline $\begin{array}{c}\text { Sperm count range } \\
\text { (million/ml) }\end{array}$ & No. of cases \\
\hline Azoo spermia & 10 \\
\hline $0-20$ & 48 \\
\hline $20.1-40$ & 20 \\
\hline $40.1^{\prime}-60$ & 10 \\
\hline $60.1-80$ & 10 \\
\hline $80.1-100$ & 2 \\
\hline Total & 100 \\
\hline
\end{tabular}


Effect of Aerobic Bacterial Infection....

Table (2)Abnormal Morphology of semen

\begin{tabular}{|c|c|}
\hline Percentage $\%$ & No. of patients \\
\hline $10-20$ & 4 \\
\hline $20.1-30$ & 2 \\
\hline $30.1-40$ & 14 \\
\hline $40.1-50$ & 3 \\
\hline $50.1-60$ & 25 \\
\hline $60.1-70$ & 5 \\
\hline $70.1-80$ & 10 \\
\hline $80.1-90$ & 27 \\
\hline $90.1-100$ & 10 \\
\hline total & 100 \\
\hline
\end{tabular}

Table(3): types of isolated microorganism

\begin{tabular}{|c|c|}
\hline Types of microorganism & No. (total) \\
\hline E. coli & 4 \\
\hline Staphylococcus aureus & 16 \\
\hline$\beta$-haemdytic Streptococci & 1 \\
\hline Total & 21 \\
\hline
\end{tabular}

Table (4): Microscopical findings

\begin{tabular}{|c|c|}
\hline Findings & No. \\
\hline Red blood cells & 13 \\
\hline Epithial tissue(debris) & 17 \\
\hline Pus cells & 20 \\
\hline Candida Spp & 2 \\
\hline Spermatocytes & 5 \\
\hline Urate crystale & 8 \\
\hline
\end{tabular}




\section{Reference}

1.Wn F.C. ,and Bancroft H.j. Br.Med.J 290: 1417-1420. (1985)

2.Hacher, Moore. Essentials of obstrices and Gynecology, $2^{\text {nd }}$ Ed. W.B. Saunders company, U.S.A. (1992).

3.Giblin P. T.W. Poland M.L., Olson J.M., and Moghissi I.S. Fertil.49: 127-132.( 1988)

4.Booth J., Merriam G.R. Clark R. V., Loriaux L.D. and Sherins R. J. J. Clin. Endocrinol. Metab.64 : 1194-1198 (1987).

5.Kandeel F. R., and swerdloff R.S. Role of temperature in regulation of speratogensis and the use of heating as method for contraception . Fertile. Sterile.49: 1-23.(1988)

6.Johnson L.,Abdo J.G.,petty C.S and Neaves W.B. Fertil . Steril 49:1045-1051(1988)

7.Auroux M D D ,Semen examination Chapter 22.In : Gradwohls' clinical laboratory methods and diagnosis, volume one. Ed Sonnewirth \& Jarret, pp.501,Mosby-London.(1980)

8.Bar-Chama N., Fisch L., Infection and pyospermia in male infertility. Department of Urology, Montefiore Medical, Center , Albert Einstein College of Medicine, Bronx. N.Y. World L. Urol.11 (3) :76-81 (1993). 9.Preveden, T; Jovasnvic, J R and Stic, D. Abstract (1996). 